\title{
'GREENFIELDS' AND 'BROWNFIELDS': AUTOMOTIVE INDUSTRIAL DEVELOPMENT IN THE UK AND IN PORTUGAL ${ }^{1}$
}

\author{
ANDREW PIKE ${ }^{2}$ \\ MÁRIO VALE ${ }^{3}$
}

\begin{abstract}
The industrial policy in the UK and in Portugal, as in most EU countries, seeks to attract new inward investment capacity, to create jobs and to promote the impact of the so-called 'demonstration effect' of 'greenfield' development strategies pursued in the new plants of inward investors on existing or 'brownfield' plants. This industrial policy focus is particularly evident in the automobile industry.

This paper compares the industrial policy oriented toward the automobile industry in the UK and in Portugal. Two recent 'greenfield' investments are analised: Nissan in the Northeast region (UK) and Ford/VW in the Setúbal Peninsula (Portugal), as well as three 'brownfield' plants: Ford Halewood and GM Vauxhall Ellesmere Port in the North West region (UK) and Renault in Setúbal (Portugal). The first part starts with a discussion of industrial policy in the automobile sector, the role of 'greenfield' development strategies and the 'demonstration effect' on 'brownfield' plants. Then, the limits of new inward investment are pointed out, basically their problems and restrictions. Afterwards, the structural barriers to the 'demonstration effect' within 'brownfield' plants are outlined and some possibilities for alternative 'brownfield' development strategies are presented.
\end{abstract}

Key-words: industrial policy, automobile industry, 'Greenfield' and 'Brownfield' Plants, UK, Portugal.

Resumo - 'GREENFIELDS' E 'BROWNFIELDS': INDÚSTRIA AUTOMÓVEL NO REINO UNIDO E EM PORTUGAL - A política industrial no Reino Unido e em Portugal, como na maior parte dos países da União Europeia, tem por objectivo a atracção de investimento directo estrangeiro (IDE), a criação de emprego e a difusão de 'efeitos de demonstração' das estratégias de desenvolvimento das novas unidades produtivas ('greenfield') nas unidades já existentes ('brownfield'). Estas orientações da política industrial são particularmente visíveis no sector automóvel.

Neste artigo, procuramos comparar a política industrial orientada para a indústria automóvel em Portugal e no Reino Unido. Analisam-se dois investimentos do tipo 'greenfield' (Nissan na região do Northeast de Inglaterra e Ford/VW na Península de Setúbal, em Portugal) e

1 This article is based on a paper presented in the EUNIT Seminar, Naples 22-24 November, 1995. A previous paper focused only on the UK situation was published by PIKE, A. (1996) Greenfields, brownfields and industrial policy for the automobile industry in the UK. Regional Studies, 30 (1): 69-77.

${ }^{2}$ Lecturer at CURDS, University of Newcastle Upon Tyne, Newcastle Upon Tyne NE1 7 RU, U.K.. Tel: (44-191) 22280 19; Fax: (44-191) 23292 59; e-mail: a.j.pike@ncl.ac.uk

${ }^{3}$ Assistente da Faculdade de Letras da Universidade de Lisboa. Investigador do CEG. Centro de Estudos Geográficos, Universidade de Lisboa, Cidade Universitária, 1699 LISBOA Codex. Tel: (351-1) 79402 18; Fax: (351-1) 79386 90; e-mail: ceg@ mail.telepac.pt 
três investimentos de tipo 'brownfield' (Ford Halewood e GM Ellesmere Port na região do North West de Inglaterra e Renault igualmente na Península de Setúbal).

Iniciamos este artigo com uma discussão da política industrial no sector automóvel, focando o papel das estratégias de desenvolvimento de tipo 'greenfield' e o 'efeito de demonstração' nas unidades existentes. Em seguida, mencionamos alguns limites do IDE no sector na indústria automóvel. Finalmente, apontamos as barreiras estruturais ao 'efeito de demonstração' nas unidades produtivas de tipo 'brownfield', fornecendo igualmente algumas alternativas para a estratégia de desenvolvimento destas unidades produtivas.

Palavras-chave: política industrial, indústria automóvel, 'Greenfield', 'Brownfield', Reino Unido, Portugal

\section{INTRODUCTION}

The industrial policy in the UK and in Portugal, as in most EU countries, seeks to attract new inward investment capacity and jobs, and to promote the impact of the so-called 'demonstration effect' of 'greenfield' development strategies pursued in the new plants of inward investors on existing or 'brownfield' plants (OLIVER and WILKINSON, 1990). This policy has been especially evident in the automobile industry in the UK since it has been regarded by Conservative Governments as representative of the 'British disease', characterised by low productivity, poor quality, shop floor militancy as well as weak management and inadequate control of labour costs (MARSDEN, MORRIS, WILLMAN and WOOD, 1985).

In Portugal the automobile productive system has been considered by the Government as a master piece for national economic efficiency and for regional development. However, the national strategy is not limited to the attraction of new investments, it also focuses on high technology initiatives and pays particular attention to the integration of the automobile plants at the local and regional levels. The situation in Portugal is rather different from the UK reality, not least due to the longer history of production in the UK, although the automobile industry can be characterised by the specialisation on assembly lines, taking advantage of low wages, and an infant components industry.

Much research has examined the levels and nature of inward investment and the characteristics of the automobile 'transplants' in the UK (DICKEN, 1992; JONES and NORTH, 1991). These works generated debates concerning industrial strategy, investment levels, job creation, new labour processes and working practices, reconfigured labour-management relations, new supplier linkages and levels of local component sourcing. Indeed, the 'Japanisation' debate received much attention in the 1980s (see, for example, OLIVER and WILKINSON, 1990; WOOD, 1992). However, relatively less research has examined the longer term impacts of the UK industrial policy in the automobile industry.

Research in the automobile sector in Portugal is insufficient, however the recent growth perspectives of the sector have generated research analysis in the field of economy, sociology and geography (GUERRA, 1990; MONIZ, 1993; LIMA et al, 1995; FERrão and VALE, 1995; GAMA, 1995; GARrinhAS, 1996). The focus of these analyses is oriented toward foreign investment and its connections with regional productive linkages. The recent Ford/VW investment, one of the largest and most high profile in recent years in the automobile industry on the European scale, has stimulated the debate on the role of direct foreign investment as a means to support economic growth and to improve the competitive level of national components industry. This sector is considered a major growth prospect in 
the future and in consequence has been highly emphasised by the industrial policy in Portugal. The Ford/VW project is a central element to obtain a qualitative change in the sector, seeking to promote intra-sectoral specialisation in deep contrast with the inter-sector specialisation promoted by national authorities in the past (FERRÃO and VALE, 1995).

This paper redresses the shortfall in the nature and level of automotive industrial research in the UK and Portugal. Several key issues are addressed, comprising the industrial logic of allowing new entrants into the EU market, regional shifts in automobile industry employment, the maturing of 'greenfield' development strategies, the limits of the 'demonstration effect' in 'brownfield' plants and alternatives 'brownfield' development strategies.

The research from which the evidence is drawn examined in the UK one 'greenfield' plant, Nissan Sunderland in the North East region, and two 'brownfield' plants, Ford Halewood and GM Vauxhall Ellesmere Port in the North West region (PIKE, 1994). Nissan's 'transplant' was established in 1986 as the firm's bridgehead in the Single European Market ${ }^{4}$. Halewood and Ellesmere Port were established in the early 1960s to expand model ranges and supplement vehicle assembly and component building capacity. In Portugal, the work focused on the Ford/VW 'greenfield' plant at Palmela ${ }^{5}$ and, one 'brownfield' plant, Renault Portuguesa at Setúbal, both of which are in the Lisbon and Tagus Valley region. Ford/VW started the production of a multi-purpose vehicle in 1995 for the European market. Renault's plant was established in 1980 to produce passenger cars and light commercial vehicles for the national market and to other countries in Europe and, at present, can be considered a singular case in the European automobile panorama ${ }^{6}$.

The paper is divided into five sections. First, industrial policy in the automobile industry, 'greenfield' development strategies and the 'demonstration effect' are outlined. Second, the limits of 'greenfield' strategies are discussed. Third, the structural barriers to the 'demonstration effect' within 'brownfield' plants are detailed. Fourth, the possibilities for alternative 'brownfield' development strategies are briefly presented. Finally, some conclusions about the industrial policy towards the automotive sector in the UK and Portugal are drawn.

\section{1 - INDUSTRIAL POLICY IN THE AUTOMOTIVE INDUSTRY IN THE UK AND PORTUGAL}

\section{1 - UK: 'greenfield' development strategies and the 'demonstration effect'}

UK industrial policy in the 1980s and early 1990s aimed to attract inward investment to the UK from Far Eastern (particularly Japanese) sources, especially in the strategic and technologically intensive automotive and electronics sectors. The benefits were seen as investment in industrial capacity, jobs and that «inward

\footnotetext{
${ }^{4}$ Nissan's investment has recently topped the $£ 1$ bn level and much of the recent investment has been to shield the European operations from the strength of the Yen. For example, the recent $£ 26 \mathrm{~m}$ axle plant was established to replace the increasingly costly imports from Nissan Motor in Japan.

5 According to Ford/VW, the AutoEuropa project is one of the largest investments in the automobile industry in recent years, representing an overall investment of ECU 2,550 million.

${ }^{6}$ After a long period of divergence between Renault and the Portuguese state, it was agreed that Renault plant at Setúbal would be sold to the Portuguese government on the condition that Renault would keep in production their other automobile components plants in Portugal. Renault was also committed to buying the Palmela plant's output of Renault Clios until the end of the vehicles life cycle.
} 
investment brings world class production techniques, technical innovation and managerial skills, which can be transferred to local companies» (HM GOVERNMENT, 1994, p. 94). In particular, the automotive sector was highlighted as an industry whose international competitiveness had been 'revived' by such investment. Indeed, in addition to the direct effects:

«the indirect benefits have also been profound. The arrival of world-class Japanese manufacturers, with associated component suppliers, in three areas of England (the North East, Derbyshire, the M4 corridor) and North Wales has spurred established producers to greater efforts. Continuous improvement has resulted in higher productivity, improved quality and increased reliability of parts» (HM GOVERNMENT, 1994, p. 94).

The general aim of the industrial policy has been twofold. First, to 'win' mobile investment and create industrial capacity (with export potential) and jobs in 'greenfield' plants in the UK. Second, to provide a 'demonstration effect' to the existing producers in 'brownfield' plants and encourage them to upgrade their competitiveness. First, the attraction of inward investment mainly focused on bringing in major 'flagship' projects to 'greenfield' sites. The industrial policy belied also the Government's regulatory strategy for the UK economy. Key attractions promoted to inward investors included the low corporate and personal taxation rates, favourable exchange rate (especially for exports), low labour and social costs, de-regulated labour utilisation context, and the 'opt-out' from the Social Chapter of Maastricht but, crucially, the retained position within the Single European Market. Other elements emphasised included the «high labour quality and flexibility», «deregulated business environment» and «the warmth of welcome and attitude of Government and investment promotion agencies» (HM GOVERNMENT, 1994, p. 94). A favourable grant regime was also integral to the policy. In addition to the Structural Funds support, the discretionary Regional Selective Assistance (RSA) was increasingly linked to the character of such investment. The emphasis on new entrants in 'greenfield' plants was central to the message of 'renewal' and 'renaissance' to change the character of the manufacturing base in the UK. The transplants also enjoyed substantial political support, with the Government 'fighting their corner' in EU debates concerning output levels, local content and the free circulation of vehicles within the Single Market (SADLER, 1993). In its own terms, the Government can claim some success for the first part of its industrial policy. In the automotive industry, over half (57\%) of the investment in Japanese vehicle assembly capacity and over one third of the jobs within the EU are in the UK (Table I).

The second 'demonstration effect' strand of the policy linked explicitly to spreading the benefits achieved by new inward investors pursuing 'greenfield' development strategies in new 'greenfield' sites to other existing producers operating in 'brownfield' sites. These benefits comprise the ability to start afresh and implement 'state of the art' approaches in several key areas: physical site and services, plant equipment and layout, recruitment and labour-management relations, and supplier linkages. Site and services benefits included choosing an appropriate site, planning the situation of the plant and assembling the site and services to specification (often paid for at least in part by the local authorities) ${ }^{7}$ as well as building the plant to order.

\footnotetext{
${ }^{7}$ Some controversy has arisen in relation to land deals put together to attract inward investors. For example, the European Commission made Toyota pay an extra $£ 4.2 \mathrm{~m}$ for the 580 acre site it
} 
For plant equipment and layout, 'greenfield' plants can invest in 'state of the art' production technologies, introduce 'lean' production techniques, lay out the plant for maximum flow and efficiency as well as integration with suppliers. For recruitment and labour-management relations, benefits included selective recruitment and establishing relations and modes of engagement with new employees and trades unions afresh (if at all) ${ }^{8}$. 'Greenfield' plants employing markedly different forms of 'Human

Table I - Japanese Vehicle Assembly Transplants: Projected Capacity and Employment in Western Europe, 1994

Quadro 1 - Transplantes Japoneses na Montagem de Veículos: Estimativas de Capacidade e de Emprego na Europa Ocidental, 1994

\begin{tabular}{|c|c|c|c|c|c|}
\hline Company & Location & $\begin{array}{c}\text { Estimated } \\
\text { Capacity }\end{array}$ & $\begin{array}{c}\text { Capacity } \\
(\%)\end{array}$ & $\begin{array}{c}\text { Estimated } \\
\text { Employment }\end{array}$ & $\begin{array}{c}\text { Employment } \\
(\%) \\
\end{array}$ \\
\hline Honda & Swindon & 200,000 & 11.1 & 1,300 & 5.3 \\
\hline $\mathrm{IBC}^{1}$ & Luton & 100,000 & 5.6 & 1,800 & 7.3 \\
\hline $\mathrm{Mazda}^{2}$ & Dagenham & 25,000 & 1.4 & - & - \\
\hline Nissan & Washington & 400,000 & 22.3 & 4,076 & 16.6 \\
\hline Toyota & Burnaston & 300,000 & 16.7 & 2,000 & 8.1 \\
\hline UK Sub-Total & & $1,025,000$ & 57.0 & 9,176 & 37.3 \\
\hline Nissan & Barcelona & 200,000 & 11.1 & $6,750^{3}$ & 27.5 \\
\hline Suzuki ${ }^{4}$ & Linares & 150,000 & 8.3 & $2,800^{5}$ & 11.4 \\
\hline Spain Sub-Total & & 350,000 & 19.5 & 9,550 & 38.8 \\
\hline Daihatsu & Italy & 60,000 & 3.3 & 400 & 1.6 \\
\hline Mitsubishi-Volvo 6 & $\begin{array}{l}\text { Ghent, } \\
\text { Netherlands }\end{array}$ & 200,000 & 11.1 & 1,800 & 7.3 \\
\hline Suzuki & $\begin{array}{l}\text { Esztergom, } \\
\text { Hungary }\end{array}$ & 50,000 & 2.8 & 1,300 & 5.3 \\
\hline Toyota $^{7}$ & $\begin{array}{l}\text { Hannover, Ger- } \\
\text { many }\end{array}$ & 100,000 & 5.6 & - & - \\
\hline $\begin{array}{l}\text { Toyota/Salvador } \\
\text { Caetano }\end{array}$ & Lisbon, Portugal $^{8}$ & 12,000 & 0.7 & $2,360^{9}$ & 9.6 \\
\hline Other Sub-Total & & 422,000 & 23.5 & 5,860 & 23.8 \\
\hline Total & & $1,797,000$ & 100.0 & 24,586 & 100.0 \\
\hline
\end{tabular}

Notes:

1 IBC (Isuzu Bedford Company) is a GM (60\%)/Isuzu (40\%) joint venture;

2 Mazda agreed with Ford to produce 30,000 vehicles at Dagenham;

3 Includes related component suppliers;

4 Suzuki Linares' future is in doubt following Suzuki's losses in Japan and the negotiations for a rescue package, meeting permitted state aid regulations, between the Spanish national and regional governments and the European Commission;

51991 figure;

6 Volvo Car BV, formerly $70 \%$ owned by the Dutch Government, established a joint venture with Mitsubishi to produce the 'NedCar', following the sale of a 33.3\% stake from the Dutch state to Mitsubishi, and a $3.3 \%$ stake sale to Volvo, to create a joint venture based on equal equity holdings;

7 Joint production with VW;

8 We exclude production agreements between Japanese and Portuguese automotive enterprises (namely Mazda) and we are not taking in account the recent investment of Mitsubishi in Portugal;

9 Includes related component suppliers.

acquired for its Burnaston assembly plant after it suspected Derbyshire County Council of selling the site at an artificially low price of $£ 18.3 \mathrm{~m}$, which constituted illegal state aid (see PIKE, 1994).

${ }^{8}$ Honda's Swindon plant is non-union and no recognition agreement has been signed. Nissan and Toyota have single union deals with the AEEU and IBC is a multi-union plant. 
Resource Management' strategies have also helped both to create and profit from the 'new realism' in industrial relations in the UK (BEARDWELL, 1992). Supplier relations benefit from establishing linkages with suppliers afresh, often nearby assemblers to enable JIT logistics, a site and factory layout capable of rapid JIT turnaround, standardised supplier selection and accreditation procedures. New assemblers also have strong bargaining positions vis a vis suppliers due to their long term supply contracts and significant component spend. Indirect 'knock-on' effects of 'greenfield' plants include joint training and standard setting, links with universities and involvement in organisations representative of local employers (COOPERS \& LYBRAND DELOITTE, 1991) ${ }^{9}$. For UK industrial policy, the benefits of 'greenfield' development strategies have been portrayed as the solution to the 'British Disease' allegedly evident in the 'brownfield' plants of existing automotive producers.

Much has been claimed for the impact of the 'demonstration effect'. Advocates have accentuated the «infectious example» set by the introduction of «...new skills and new methods to regional economies» and celebrated the success of attracting inward investment in an increasingly competitive global market place (Peter Lilley, former Trade and Industry Secretary, quoted in TOMANEY, 1991, p. 10). Earlier in the 1980s, Norman Tebbit, then Trade and Industry Secretary, also emphasised the 'demonstration effect': «Nissan has high productivity. It has good labour/management relations. Everything is an object of envy for us. We want them to set up in Britain to demonstrate to our auto makers... these aspects of Japanese industrial management» (quoted in CAITS, 1991, p. 1).

The positive impact on the performance and competitiveness of UK suppliers, particularly for product development, quality assurance, plant and machinery, delivery times and cost control has also been emphasised (PA CAMBRIDGE ECONOMIC CONSULTANCY, 1995). WOMACK et al. (1990) underline the ability and superior performance of transplants in employing 'lean' production techniques. SADLER (1993, p. 8) notes that «The UK government's favourable attitude to Japanese assemblers rested upon their potential transformatory impact upon labour relations, automotive component manufacturers and other assemblers». POLLERT (1992, p. xxiii) stresses that «greenfield sites... arguably provide the best opportunities for the most strategic implementation of new functional flexibility in 'Japanisation' policies». The national representative organisation SMMT (Society of Motor Manufacturers and Traders) even claimed that the adoption of Japanese techniques had transformed the automobile industry in the UK «into the most exciting and influential of the 'sunrise' industries», such that «at the centre of Britain's industrial renaissance is the motor industry» (SMMT, 1989, p. 1). A substantial degree of optimism has accompanied the apparent success of the UK industrial policy in the automobile industry. However, the optimism appears rather misplaced when the more enduring questions of industrial logic, absolute and relative regional employment change and the ephemeral nature of 'greenfield' development strategies are considered.

\footnotetext{
${ }^{9}$ Ian Gibson, ex-Ford Manager in the 1970s and now Chairman of Nissan Sunderland, has also been appointed to the Society of Motor Manufacturers and Traders (SMMT) executive. The first time a Japanese company has gained representation within the main national lobbying organisation for the UK motor industry.
} 


\section{2 - Portugal: 'greenfield' development strategies and competitive}

improvement

The small size of the Portuguese market has been the main constraint to the establishment of a competitive automotive industry. FERRÃO and VALE (1995) argue that this constraint was reinforced by the failure to create a nationally-owned motorcar industry due to the Portuguese Government's non-interventionist policy stance in the Estado Novo period (New State). Industrial activity was not seen as a priority at that time. However, the economic shifts in Portugal and the need to be part of EFTA produced the necessary conditions for a change in the nature of development policies. Since the 1960's some efforts were made in order to establish an import-substitution model of economic growth. In the automobile sector severe restrictions upon the import of CBU (Completely Built-Up) vehicles were put in place and, at the same time, the Government decreed that vehicles were to be assembled in Portugal on the basis of at least 15 per cent Portuguese share of value-added (MIE, 1991).

These policy limitations in the automotive industry led to severe difficulties for several car manufacturers and, by the end of 1970's, another legal framework was developed. In 1979 the automobile sector came under a jurisdiction - Motorcar-Industry Act no. 351/79 - which intended to reconvert the assembly lines and to promote the components industry. In fact, if the industrial policy towards the automobile industry had not changed the closure of the assembly lines and subsidiary industries would have been inevitable (GUERRA, 1993). The new legal framework allowed the restructuring of the automobile industry by focusing on both the vehicle assembly lines and the components industries.

The most significant result of this policy is observable in the Renault Project. This firm was selected in the international bidding process and it demanded as a necessary condition the need for a temporary market protection which became a reality with the support of European authorities and EFTA. GUERRA (1993) concludes that, in this sense, the Renault Project was instrumental to the consolidation of the export promotion policy.

Portuguese industrial policy since the second half of the 1980's has focused on the attraction of further foreign direct investments. The new objectives of the industrial policy were a consequence of the integration of Portugal into the EU and, at the same time, the change of Government to the Centre-Right Social Democratic Party (PSD).

As in the UK, the industrial policy in the automobile sector is twofold. First, to attract inward investment, both in car assembly and in component manufacture. Second, to create and to reinforce the national components industry. The first policy goal focused on the attraction of foreign direct investment (FDI), particularly from the other EU countries and also from Brazil and the Far East (although the FDI from non-EU countries is relatively low in the automobile sector). The investments in the automotive industry were seen by the Government as:

«...those fields of activity are chosen where it will be presumably difficult for the Portuguese investors to participate alone, due to the existing barriers, such as technology, scale and financial capacity problems. The automobile components business is the best example of field where the required progress and updating is practically only possible through foreign investment. This is evidenced by Renault project around which a whole group of national companies flourished» (MIE, 1991, p. 8-9). 
The relevance of the automobile sector in Portugal is evident and recently PORTER ${ }^{10}$ stressed the possibilities for a cluster creation. As in the UK case the industrial policy ought to work horizontally, to integrate deeply this filière, and to link with other related sectors (textile, electronics, rubber and plastic, metal products) (GARRINHAS, 1996).

Through this industrial policy, the automotive sector was expected to create industrial capacity and jobs. In employment terms, the Government is paying particular attention to training, as a consequence of the traditional low skills level of Portuguese workers. The 'greenfield' investments are meant to achieve and diffuse new labour practices and to sustain the 'enterprise culture'. As in the UK, the traditional trade union organisations play a more limited role than in the past and in the new projects their strength is relatively low.

The sector is also expected to increase the level of exports, although the weakness of the national productive fabric in the components industry has generated a growth in imports. To rectify this situation, not only the quantity but also the quality of the products is stressed, where the 'greenfield' investments are again the easiest way to achieve this goal. The attraction of 'greenfield' investments is based in the progressive quality of the business environment of some Portuguese regions (mainly the North and the Lisbon and Tagus Valley regions). This is the case whether it concerns infrastructures (high improvements on accessibility) or better supply of business-related services. These benefits comprise physical site and services, plant equipment and layout, recruitment and labour-management relations and supplier linkages.

The second objective of the Portuguese industrial policy is related to the strength of the automobile components industry. The Government argued that the easiest way to achieve this policy goal was to base it on the attraction of inward investment. The promotion of 'greenfield' investments in the vehicles assembly sector was thought to provide the supply linkages with the highest possible level of components made in Portugal. As the quality and the technological level of the required components are crucial to the car makers, the Portuguese components industry would then be stimulated by this challenge and would have to improve their competitive level in terms of output capacity, technology, quality, labour skills and work organisation.

In order to improve competitiveness of the national components suppliers, a quality and stable market has in effect been created in Portugal, at least for a reasonable period which has been supplemented by inward investment. The Renault project was an important instrument to consolidate and to expand the national components industry. It is expected that the Ford/VW project would have a similar or even more prolific effect due to the high quality of the product and the amount of investment involved in the formation of this joint-venture ${ }^{11}$.

The demonstration effect occurring in the UK is more oriented towards the components industry in Portugal rather than the vehicle assembly lines. With this stimulus, the Government expect the sector to become more competitive internationally, particularly in the EU, to export higher quality products and gain a

10 MONITOR COMPANY (1994) - Construir as Vantagens Competitivas de Portugal. Monitor Company, Lisboa.

11 The overall investment reaches ECU 2,550 million and the incentives and tax exemptions represent ECU 750 million. Ford/VW plant produces a people carrier, and the maximum output capacity is 180,00 vehicles/year. Around $99 \%$ of production is for the European market. The figures for the employment were initially forecasted in 5,000 direct jobs, but in fact a little more than direct 3,000 jobs were created. 
more important place in the automobile supplier networks across Europe. In fact, since Ford/VW started production in 1995, the turnover of automobile components industry in Portugal rose by $9 \%$, and the domestic market rose be nearly $15 \%$. However, in 1995, the exports represented $79 \%$ of the turnover in this industry ${ }^{12}$.

State financial assistance has played a significant role in the Portuguese industrial policy. To achieve their goals the Government provided considerable support for both Renault and Ford/VW. Although the cost/productivity ratio of manpower is above the EU average (MIE, 1991), the peripheral position of Portugal has to be compensated by financial support. Tax exemptions, grants, the low cost of industrial sites and state aids for job-training are the direct forms of financial support used until now by the national authorities. These have a national component as well as a European one, through the structural funds (ERDF and ESF). The PEDIP (Specific Programme for Portuguese Industry Development) and SIBR (Regional Incentives System) are the specific national programmes that support both national and international enterprises.

\section{2 - PROBLEMS AND LIMITS TO 'GREENFIELD' DEVELOPMENT STRATEGIES}

In terms of industrial logic, the arrival of the Japanese transplants has added to substantial overcapacity within the European automobile industry. Recent estimates calculate a level of $1-1.2 \mathrm{~m}$ vehicles (DICKEN, 1992), roughly equivalent to the transplant capacity established in the UK. In Europe, this overcapacity equals the total output of one of the 'Big 6' automobile groups (VW, GM, PSA, FIAT, Ford and Renault). Overcapacity has led to intensified competition and the rationalisation of capacity, primarily amongst the 'brownfield' plants of existing producers which have further to travel to become competitive or to close down and establish 'greenfield' plants elsewhere. Further, the transplant capacity has been supported, depending on its locational eligibility, by a whole array of national and European grant measures, which have only been captured by existing producers when they have been investing rather than going through the current retrenchment.

\section{1 - The UK restructuring process}

Several questions arise from the entry of Japanese capacity into the UK. First, the addition of the transplants may still be insufficient to offset, and may even aggravate, the balance of payments pressures present within the sector. Historically, due to the large size of the UK car market (often 2nd or 3rd largest in the EU), weak export performance and the high propensity for import penetration, both from foreign and UK-based producers (so-called 'tied' imports) of vehicles and components, has meant the sector runs a trade deficit. The transplants have reinforced such problems due to the narrow range of products produced within the UK (e.g. only Nissan Sunderland produces two different models). This strategy requires vehicle imports to complete the model range and the import of high value-added components (especially transmissions, engine blocks and other precision forgings $)^{13}$. Moreover, the explicit commitment by the transplants to export a

12 This information is based on a recent report of the Portuguese Automobile Manufacturers Association (AFIA), diffused by the media, namely Diário de Notícias, 7/10/96.

13 A large majority of capital equipment in the transplants is also imported, often from Japan (PIKE, 1994). 
proportion of their output is made on the back of expanding levels of production, leaving more units to be sold in the domestic UK market. Second, ownership is central and evidence suggests Japanese capital maintains substantial component and vehicle production in Japan, supported by centralised corporate R\&D laboratories, and affiliated suppliers have been encouraged to internationalise (often since they have cross-shareholdings), and profit repatriation is to be expected once transplant investments have been amortised (WILLIAMS et al., 1992). In combination, these issues suggest that the industrial logic of allowing the entry of Japanese transplant capacity is not as clear as the UK industrial policy assumes.

In terms of job creation the picture is more accurately described as net job displacement. Approximately 9,000 jobs in total have been created directly in the UK plants of Honda, Isuzu, Nissan and Toyota. Indirect employment in suppliers to the four plants has been estimated at 6,000 jobs (ECONOMISTS ADVISORY GROUP/IWG, 1994; PIKE, 1994). Total direct and indirect employment is approximately 14,576. While substantial, this jobs total fails even to compensate for the 28,000 losses within Ford and GM Vauxhall alone in the UK between 1960 and 1992 (PIKE, 1994). In addition, total employment in the motor vehicles and components sector fell from close to 500,000 to nearly 200,000 between 1974 and 1992 (Employment Gazette, Various Issues). As Ford note in their criticism of UK industrial policy, the picture is one of substantial net job loss:

«...in real terms, for every one Japanese company job that is generated, helped by government support, there must be two or three that are lost elsewhere in the industry. So if you net it out it is going to look like not a good decision to make» (Ford Motor Company Manager, cited in PIKE, 1994, p. 398).

While all of the employment losses can clearly not be linked directly to the arrival of Honda, Isuzu, Nissan and Toyota, the impending European market liberalization and the rapid gains in market share of the Japanese producers elsewhere in Europe appear to have promoted job rationalization amongst the existing automobile producers in the UK. While the threat of Japanese competition has been used by existing manufacturers for many years, the situation appears not to be one of 'crying wolf' any longer. Indeed, Ford have used their criticism of the transplants to justify their own actions:

«With the growing presence of Japanese transplant facilities in Britain operating with the advantages of a greenfield site and extremely low levels of engineering and manufacturing integration, it should not be surprising that an established company such as Ford must shed labour to ensure its future competitiveness and prosperity» (Ian McAllister, Ford UK Chairman quoted in FORD MOTOR COMPANY, 1992).

The map of automobile production jobs within the UK has also been redrawn. 'Greenfield' regions, those lacking a pronounced history of automobile manufacture, have seen relative growth (Table II). In total, employment in the UK automobile industry declined by over $34 \%$ between 1981 and 1991, a loss of 120,500 jobs. Over the same period, however, only the Northern region, (including Nissan and its suppliers) and, to a lesser extent, Yorkshire and Humberside exhibited modest growth from low base figures, increasing the number of 
automobile jobs from 7,100 to 8,100 and 12,300 to 13,100 respectively. The East Midlands (including Toyota and its suppliers) also exhibited a markedly lesser decline than other regions. Elsewhere in the UK employment in the sector declined substantially. Scotland, Wales, London and the South East all lost over $40 \%$ of their automobile-related employment, some 60,800 jobs and the North West and West Midlands both declined by over 30\%, losing over 58,000 jobs. In total, the sector declined from over $1.6 \%$ of total UK employment to just over $1 \%$ between 1981 and 1991. Significantly, in England the South East, West Midlands and North West regions experienced the sharpest declines in shares of total employment, approaching half in each region. Elsewhere, only Yorkshire and Humberside and the Northern region registered growth. These increases came from a low base and failed to compensate for declines elsewhere. In addition, not only are the new jobs in the automobile sector geographically removed from those labour markets where they have been lost - implying at least some degree of labour mobility - but the new jobs are often in 'greenfield' plants which have exercised their ability to pursue rather different recruitment practices than those historically characteristic of the industry. The old skills and attitudes of unemployed car workers are unlikely to find employment in such plants ${ }^{14}$.

Table II - Change and Share in Motor Vehicles and Parts Sector Employment in the UK, by Region, 1981-91

Quadro II - Variação e Distribuição do Emprego na Indústria Automóvel no Reino Unido, por Regiões, 1981-91

\begin{tabular}{|c|c|c|c|c|c|}
\hline \multirow[t]{2}{*}{ Standard Region } & \multirow{2}{*}{$\begin{array}{l}\text { Year } \\
1981\end{array}$} & \multirow{2}{*}{$\begin{array}{l}\text { Year } \\
1991\end{array}$} & \multirow{2}{*}{$\begin{array}{l}\text { Change (\%) } \\
1981-1991\end{array}$} & \multicolumn{2}{|c|}{$\begin{array}{c}\text { Share of Total Employment } \\
(\%)\end{array}$} \\
\hline & & & & 1981 & 1991 \\
\hline South East & 68,880 & 40,600 & -41.06 & 1.87 & 1.03 \\
\hline East Anglia & 5,100 & 4,400 & -13.73 & 0.75 & 0.56 \\
\hline London & 33,400 & 17,300 & -48.20 & 0.94 & 0.53 \\
\hline South West & 9,400 & 8,000 & -14.89 & 0.61 & 0.47 \\
\hline West Midlands & 114,800 & 74,700 & -34.93 & 5.65 & 3.67 \\
\hline East Midlands & 10,200 & 9,700 & -4.90 & 0.70 & 0.64 \\
\hline $\begin{array}{ll}\text { Yorkshire } & \text { and } \\
\text { Humberside } & \end{array}$ & 12,300 & 13,100 & 6.50 & 0.67 & 0.71 \\
\hline North West & 53,300 & 34,500 & -35.27 & 2.17 & 1.46 \\
\hline Northern & 7,100 & 8,100 & 14.08 & 0.63 & 0.74 \\
\hline Wales & 19,400 & 10,500 & -45.88 & 2.07 & 1.09 \\
\hline Scotland & 11,300 & 3,700 & -67.26 & 0.57 & 0.18 \\
\hline UK Total & 345,100 & 224,600 & -34.92 & 1.62 & 1.04 \\
\hline
\end{tabular}

Source: NOMIS, 1991.

The limits of 'greenfield' development strategies have been evident also in the transplants since their arrival. Many of the 'first mover' advantages of establishing on 'greenfield' sites and pursuing 'greenfield' development strategies are often

14 Jim Thomas, MSF National Automotive Officer, noted of the new employment opportunities that: "I was having a debate with some of our guys in Fords at Halewood and the same would go for Ellesmere Port, I guess. They say 'look, tell the company if we don't get this we are all going to go to Toyota.' I said that Toyota won't have you. You guys are car makers, you have got bad habits. They don't see your experience as an opportunity, they see it as a disadvantage" (Author's Interview, 1992) 
diluted, if not lost altogether, with the passage of time. What WiLLIAMs et al. (1994, p. 233) term the «long descent into ordinariness». The point is that 'greenfield' plants age and mature and perhaps lose many of the benefits of being a 'greenfield' plant over time. The UK industrial policy emphasis on 'greenfield' development strategies and their 'demonstration effect' therefore looks questionable. Indeed, Halewood and Ellesmere Port were once 'greenfield' plants in the early 1960s and enjoyed many of the same benefits as the transplants did on their arrival. Both plants had the advantages of «...picking the cream of the labour market» and «green labour» not used to the rigours of assembly line manufacturing, due to the decline of traditional port-related industries and high unemployment in Merseyside (BEYNON, 1984, p. 101). However, it appears that, while the intentions were good, the practice turned out somewhat different with the passage of time:

«We went there with the idea of having a good plant; one with good labour relations. We wanted to get a trouble free plant, to get away from Dagenham and Dagenham ways. It didn't turn out like that though» (Halewood Personnel Director, quoted in BEYNON, 1984, p. 76).

Similarly, Nissan has enjoyed the 'honeymoon period' of initial plant set up and expansion. However, production had to be cut back following the downturn in the European automobile market in the early 1990s and Nissan have had to adjust to the more normal cyclical market demand within Europe. This resulted in the cancellation of the nightshift and 350 voluntary redundancies from a workforce of close to 4,500 (7.7\%). Falling output also reduced demand for inputs amongst their local supplier complex, many of which arrived in the North East solely to support Nissan's transplant. These supplier satellites often found they were of insufficient size to break into the supply chains of existing producers to secure longer term supply contracts ${ }^{15}$. Nissan have also had to persist with continuous improvement programs, the latest of which is 'NX '96', as part of attempting to reach a moving target for performance. Other Japanese investments within Europe appear also to have reached the relative limits of expansion in the European market and a degree of rationalisation is evident, for example at Suzuki Linares and Nissan Motor Iberica in Spain (DONE, 1995). This evidence presents a cautionary argument against the UK Government's industry policy emphasis on the seemingly ephemeral benefits of 'greenfield' development strategies and their example ${ }^{16}$.

\section{2 - Portugal: peripheral growth in the EU}

The automobile sector in the EU is facing a restructuring process due to the creation of the Single Market and the Japanese threat (FERRÃO and VALE, 1995). The Iberian Peninsula, especially Spain, became more specialised in automotive production. In Portugal, the processes of change are also evident, and they are closely linked to broader restructuring within Europe. The car makers in Europe have reorganised themselves on a trans-European basis and some of peripheral regions in the South and increasingly Central and Eastern Europe are integrated into this new map of automobile production.

15 Given this shock to the local cluster of suppliers, some firms have managed to diversify their customer base. TRW Valves, for example, now supply Ford, Saab and VW in addition to Nissan.

16 IRS (1993) even suggest that labour law reforms and the recession have had more influence on working methods in the UK than the example of companies like Nissan. 
The Japanese investments in Portugal are not very significant, however in terms of regional impact they are quite important (see for instance Mitsubishi, Toyota/Salvador Caetano and Yazaki Saltano).

The regional breakdown of employment shows clearly a concentration on the coastal area, mainly in the Oporto and Lisbon metropolitan areas. In fact, in 1993 the Oporto region (Aveiro, Braga and Oporto districts) had more than half of the automobile sector employment in Portugal (52\%) and the Lisbon region (Lisbon and Setúbal districts) accounted for more than about 30\% (not taking in account the employment of Ford/VW and Ford suppliers located in the industrial park at Palmela). Leiria and Viseu in the Centre region can be highlighted, the former because of the components industry and the latter related to the low volume assembly line of Citroën. A regional shift in the automotive industry was also evident in Portugal even before its reinforcement by the Lisbon metropolitan region in deep association with the Ford/VW plant and nearby suppliers.

Table III - Share of Motor Vehicles and Parts Sector Employment in Portugal, by District, 1993

Quadro III - Distribuição do Emprego na Indústria Automóvel em Portugal, por Distrito, 1993

\begin{tabular}{|l|c|}
\hline District & $\begin{array}{c}\text { Employment } \\
\%\end{array}$ \\
\hline Aveiro & 25.2 \\
\hline Beja & 0.1 \\
\hline Braga & 10.4 \\
\hline Bragança & 0.1 \\
\hline Castelo Branco & 0.2 \\
\hline Coimbra & 1.3 \\
\hline Évora & 3.0 \\
\hline Faro & 0.2 \\
\hline Guarda & 0.3 \\
\hline Leiria & 3.4 \\
\hline Lisboa & 16.2 \\
\hline Portalegre & 0.0 \\
\hline Porto & 16.5 \\
\hline Santarém & 6.4 \\
\hline Setúbal & 12.8 \\
\hline V. Castelo & 0.1 \\
\hline V. Real & 0.1 \\
\hline Viseu & 3.9 \\
\hline Total & 17,240 \\
\hline
\end{tabular}

Note: The figures presented in the table do not comprehend the employment generated by recent inward investments in the sector, both Ford/VW assembly plant and automobile components firms.

Source: MESS, 1994.

The location of the recent inward investments has stressed the importance of the Lisbon Metropolitan Area. In particular, this was due to the Ford/VW investment, which generated more than 3,000 direct jobs and more than 1,500 indirect ones (COSTA and VALE, 1996). The very recent inward investments like the Ford car air conditioning systems in Setúbal have also to be taken into account. A recent report by AFIA claimed that the overall level of employment solely 
within the components sector stood at approximately 23,500 employees, representing 150 firms, of which 10 were created in 1995.

The most important assembly lines are located in the Lisbon and Tagus Valley regions, for example Renault, Ford/VW, Opel, Ford and Mitsubishi. Only Citroën and some national producers of Japanese commercial vehicles under license are located outside this region. The 'greenfield' investments do not tend to avoid traditional manufacturing regions, especially the Setúbal Peninsula where the industrial workers maintain their collective solidarity and the presence of the trade unions remains important. This situation is completely different from the UK. Part of the difference is explained by the fact that the Lisbon Metropolitan Area has more advantages, mainly in terms of infrastructure and job skills. In other words, the agglomeration economies are more evident in this region.

In spite of the historically high risk of strikes in the region it must be said that in order to avoid this constraint, 'greenfield' production plants have recruited fresh 'green' labour with no previous work experience whatsoever in manufacturing activities. For instance, Ford/VW recruited young workers; the average age is 26 years and $90 \%$ are males. The job training has been provided by the company and the work organisation is centered on teams, which are not suitable for traditional industrial workers more used to rigid job descriptions and demarcation.

The limits of 'greenfield' development strategies are evident. Although production started only in 1995, the Ford/VW plant at Palmela has already had some problems. The initially stated objectives regarding employment and production were not achieved. In fact, the forecast creation of 5,000 jobs generated by the company and a production output of 180,000 vehicles a year were not achieved (the volume was only around 50,000 vehicles in 1995, although only by the end of the decade the full production capacity should be reached). The problem is the overcapacity in this segment (multi-purpose vehicles) in the EU. If the market does not react well to the product of Ford/VW joint-venture (which is not the case at the moment), the initial sales forecasts will not be achieved. Despite the overcapacity, Ford expects the expansion of the market through the strength of the dealer networks of Ford and VW.

As in the UK, the situation in Portugal concerning the 'greenfield' development strategy therefore looks questionable. The risks of failure of these type of projects and the limits of the 'demonstration effect' should not be underestimated by national authorities and the evaluation of the project will have to be rigorous. Nowadays the arrival of similar products to the market, production overcapacity in the EU, and participation of national suppliers only in the lower complexity components raise many questions about the capability of the project to reinforce the competitiveness of the national components industry.

\section{3 - DIFFICULTIES OF ADJUSTMENT AND ALTERNATIVE STRATEGIES FOR 'BROWNFIELD' PLANTS}

\section{1. - Limits and structural barriers}

Evidence from Ford Halewood, GM Vauxhall Ellesmere Port and Renault Setúbal reveals apparent limits, and even structural barriers, to adjustment and the 'demonstration effect' in 'brownfield' plants. First, 'brownfield' plants are marked by socially constructed attitudes, conventions and approaches which have been 
accumulated by the workforce, trades unions and management through their shared experiences in the plant.

These attitudes can act to frame and limit the ways in which change is introduced, negotiated and implemented on the part of both workforce, trades unions and management. In particular, a marked reluctance to change due to the perceived risks involved has been evident, especially in the context of an unwillingness to disturb production continuity to test new ideas. Often traditional 'right to manage' strategies based on threats of redundancies and closure have been insufficient due to the magnitude of changes required. A more progressive management approach has been required to foster the workforce commitment and reward their participation in job (re)design and kaizen activities.

Second, the pace at which adjustment to respond to the 'demonstration effect' is expected to occur is reaching effective limits, particularly given the historically and socially constructed inertia within 'brownfield' plants. These comprise the changing of job specifications within teams faster than training or workforce proficiency can keep pace with and the failure of training to provide the necessary workforce skills in the context of labour shedding. Whether, or if, adjustment to Japanese 'best practice' levels of efficiency can be reached before ultimate rationalisation and closure occurs has consequently been a cause for concern in the 'brownfield' plants. Lastly, the particular norms and expectations of an ageing workforce constructed through their particular employment histories have also hindered changes, reinforced by job rationalisation and the lack of recruitment in recent years. Substantial levels of retraining have occurred, creating a dilemma for management in investing in potential early retirement candidates. Moreover, older members of the workforce are said to be unwilling to undertake new tasks in contrast to new recruits which have had no time in which to develop expectations relating to their daily working tasks.

In addition to the apparent limits, certain structural barriers to the 'demonstration effect' are evident mainly due to the position of the plants in broader corporate structures of production. The capability to effect industrial adjustment is often hampered by plants being locked into intra-corporate competition for investment. Ford and GM's UK plants are closely integrated into pan-European (and even global) product life cycles, component supply networks and production systems. While having increased their relative autonomy and responsibility in recent years, these plants are often not free, or are unable, to raise the investment to reorganise unilaterally. Change depends on their position and perceived 'reliability' within the company. The same situation applies to Renault Setúbal where corporate-wide restructuring has led to rationalisation, posing significant problems for the workforce. Initially, redundancy and dramatic changes in work organisation were seen as fundamental to restoring the competitiveness of the plant. However, even with these changes, Renault Setúbal has had difficulties in competing with other 'greenfield' plants. In fact, the opportunities in Central and Eastern Europe has led several car makers to restructure their production network and the Setúbal plant is no longer seen as an important piece of Renault's European strategy. The perceived lack of competitiveness at the plant is a result of the broader adjustment difficulties in 'brownfield' plants due to new 'lean production' techniques, the small domestic market in Portugal (before Portugal's accession to the EU, Renault had a protected market in Portugal through a quota system), and a substantial cut of financial aids by national authorities.

The Renault administration, workers and Government (which have a capital participation in the factory) did not agree on the development strategy of the plant 
in Portugal. However, after a long period of negotiation and threats, Renault and the national authorities agreed to maintain the factory under the full responsibility of the Portuguese authorities, until the end of Clio model's life cycle. In turn, Renault guaranteed the maintenance of other components factories in Portugal, and will buy the production of Renault factory at Setúbal. Meanwhile, the Portuguese government has developed a strategy to sell this 'brownfield' factory to another automobile company (Japanese, American or South Korean), although this is proving a hard task to achieve.

None of the 'brownfield' plants have had the equivalent strategic status and autonomy of Nissan or Toyota which are their respective company's sole passenger car producing plants in Europe. 'Brownfield' plants have to compete between 'cloned' capacity plants within Europe and often concede concessions, on terms and conditions of employment for example, to 'win' intra-corporate battles for investment. The strategic map of European car manufacture is also expanding. This has become a key constraint for the 'brownfield' plants located in peripheral regions of the EU due to the recent growth of some Central and Eastern countries, particularly the Czech Republic, Hungary and Poland (VALE, 1994). Here, the cost/productivity ratio of manpower is quite positive, the market is developing, the workers' skills are adequate, and the quality of the infrastructure is reasonable. Even for 'greenfield' investments, the Eastern European countries have attracted new projects and have made it more difficult for Spain and Portugal to attract inward investment at the international level. 'Brownfield' plants are also integrated into supply networks and sourcing strategies which are geared toward volume, purchasing scale economies and efficiency at the corporate scale. Design and tooling costs, closer relations with fewer and larger suppliers as well as the integration of corporate $\mathrm{R} \& \mathrm{D}$ functions with suppliers have reinforced their lack of strategic sourcing, although not operating, autonomy. The existing plants have to address the tension between corporate level global sourcing and the desire to secure the benefits of local JIT component supply at the plant level. For the 'brownfield' plants it is often the purchasing economies of scale and links between the $\mathrm{R} \& \mathrm{D}$ centers of the assembler and major suppliers that dictate the geographies of supply lines.

Recent changes appear to have reached the technical limits of possible improvements in production layout and organisation in the 'brownfield' plants. It seems that only a more holistic and integrated approach to change, including the design and ease of manufacture of the automobiles, may further improve performance. Overall, it seems that all-round improvement is required, not simply the intensification of work, sweating the productive assets and attempting to increase productivity by assembling poorly designed products within inefficiently laid-out plants at faster rates. However, such regressive strategies appear all too often to be the manifestation of 'lean' production in 'brownfield' plants (see MORGAN et al., 1992; WILlIAMS et al., 1992). Together, the limits and structural barriers appear to undermine the effectiveness of the reliance in the UK and Portugal's industrial policy on promoting a 'demonstration effect' as the stimulus to industrial adjustment and renewal amongst assemblers and the supply industry.

\section{2. - Alternative development strategies}

The evidence presented challenges the emphasis of the UK and Portuguese industrial policy on 'greenfield' development strategies and the 'demonstration 
effect' on 'brownfield' plants in the automobile industry. Alternative conceptions of 'brownfield' development strategies - for both maturing 'greenfields' and in particular existing plants - need to be developed. It is seductive for the UK and Portuguese Governments, the European Commission and automobile manufacturers to adopt a market-led stance and argue that 'brownfield' plants that cannot adjust should be rationalised and closed. However, the implications for workers, communities and local economies which depend upon 'brownfield' plants in addition to the huge economic cost of scrapping sunk capital reinforce the need for alternative development strategies.

Central to possible alternatives is a conception of the characteristics of 'brownfield' plants which see age and experience not as liabilities but as assets. The constraints of operating in 'brownfield' plants therefore need not be a complete hindrance to development strategies. The alternative seeks to build upon, rather than discard, the legacies of workforce skills, training and traditions as well as the fixed capital investment embodied within the existing plants. In this way, the historical development trajectory of the plants, firms and localities are taken into account rather than attempting to erase and recreate them anew. The idea that 'greenfield' conditions can be established in a 'brownfield' plants is rejected, especially since this strategy is often accompanied by threats of plant rationalisation and/or closure and new investment and, increasingly, pay deals are tied to radical changes in employment terms and conditions. The renewed interest in 'brownfield' development strategies has been closely connected to the debate about 'hybridisation' and the rejection of Japanese or 'lean' production methods (BERGGREN, 1992; GERPISA, 1995; PIKE, 1994). The accumulated experience in 'brownfield' plants is interpreted as fundamental to a 'hybridisation' of the production process.

Central to 'hybridisation' is the recognition that there is not, unlike F. W. Taylor's infamous claim, 'one best way' of organising production but many different ways - 'multiple rationalities' (SALAIS and STORPER, 1990) - varying with employee, plant and locality history as well as technical requirements. The aim of 'lean' production to establish a new universal management model is challenged. BERGGREN (1992) argues that what is required is not 'dogmatic emulation' of all of its ideas but a 'dynamic synthesis' of the more progressive parts, including closer relations with suppliers and more integration between design, engineering and production to improve 'manufacturability'. In this way, plant and locally specific 'hybrid' production strategies can be formulated that work best for that plant and locality. There may be signs that as competition intensifies, automobile producers in Europe are having to focus available investment and the need for change on their existing plants. 'Brownfield' development strategies have, as a consequence, a role to play in the restructuring of automobile production networks in Europe.

\section{CONCLUSIONS}

This paper has used evidence from the automobile industry in the UK and Portugal to argue that the basis for UK and Portuguese industrial policy has been misplaced. The reliance on new inward investment pursuing 'greenfield' development strategies has resulted in net job displacement amongst existing producers, regional shifts in the number and character of employment, and the benefits of such strategies have been revealed as rather ephemeral advantages that are reduced with the passage of time. Also, further overcapacity in the UK and in 
Europe is a major result of this industrial policy. Similarly, the reliance on the 'demonstration effect' of 'greenfield' strategies on 'brownfield' plants has reached effective limits and structural barriers to such changes have emerged. In Portugal, the small size of the sector is a constraint to the development of national components suppliers which are a crucial target of the industrial policy. To develop the components sector, industrial policy should not concentrate only on the attraction of inward investment and the lessons from the UK should be considered in order to avoid future mistakes. A short sighted dash for expansion in the sector without consideration of the longer term, strategic issues may prove problematic.

The need for a policy-shift has been established. A move is needed away from the focus on the supply-side industrial policy dependent on the continuous attraction of inward investment and its knock-on effects on existing producers. A sectorally specific and regionally sensitive industrial policy for the automobile industry is required to promote 'hybridisation' based on acknowledging the skills, experiences and capital equipment of 'brownfield' plants as assets not liabilities. In this way, there may be hope yet for a robust automobile industry within the UK and in Portugal.

\section{ACKNOWLEDGEMENTS}

This paper builds on work supported by the Economic and Social Research Council (ESRC) and by Junta Nacional de Investigação Científica e Tecnológica (JNICT, PCSH/C/GEO/715/93). It is part of the Automotive Filière Study section of the European Commission funded EUropean Network on Innovation and Territory (EUNIT). The usual disclaimers, as always, apply.

\section{REFERENCES}

BEARDWELL, I. (1992) - The 'new industrial relations'? a review of the debate. Human Resource Management Journal, 2(2): 1-7.

Berggren, C. (1992) - The Volvo Experience: Alternatives to Lean Production in the Swedish Auto Industry. Macmillan, Basingstoke.

BEYNON, H. (1984) - Working for Ford. Penguin, Harmondsworth.

CAITS (1991) - New Union Strategies: Trade Union Responses to New Management Techniques. CAITS and MTUCURC, London and Liverpool.

COOPERS \& LYBRAND DELOITTE (1991) - A Study into the Knock-On Effects of Inward Investment in the English Regions. HMSO, London.

Costa, N.; M. VALE (1996) - The impact of AutoEuropa in the national and regional development in Portugal. EPRU/CEG (forthcoming), Lisboa.

DICKEN, P. (1992) - Europe 1992 and strategic change in the international automobile industry. Environment and Planning A, 24: 11-31.

DonE, K. (1995) - Eyes on the fast lane. Financial Times, 31st January.

ECONOMISTS ADVISORY GROUP/IWG (1994) - Inward Investment as an Instrument of Regional Industrial Regeneration. Report for the Anglo-German Foundation for the Study of the Industrial Society, Anglo-German Foundation, London/Bonn.

FERRÃO, J.; M. VALE (1995) - Multi-purpose vehicles, a new opportunity for the periphery? Lessons from the FordlVW project (Portugal). in R. HUDSON; E. SCHAMP 
(Eds.). Towards a New Map of Automobile Production in Europe? New Production Concepts and Regional Restructuring, Springer, Berlin.

FORD MOTOR COMPANY (1992) - Information from Ford (Press Release). Ford Motor Company Ltd, Brentwood.

GAMA, R. (1995) - Multinacionais e pequenas empresas no desenvolvimento territorial: o exemplo de Mangualde. Actas do II Congresso de Geografia Portuguesa, APG, Lisboa: 385-399.

GARRINHAS, J. (1996) - A Indústria de Componentes Automóveis: dos ajustamentos estruturais a nível global aos processos locais de desenvolvimento industrial, o caso da DELPHI Ponte de Sôr. Unpublished Masters Thesis, Departamento de Geografia, Universidade de Lisboa, Lisboa.

GERPISA (1995) - Programme international «Emergence de nouveaux modeles industriels, 1992-1995». GERPISA Reseau International, Universite d'Evry-Val d'Essone, Evry.

GuERRA, A. (1990) - Formas e Determinantes do Envolvimento Externo das Empresas. Internacionalização da Indústria Automóvel Portuguesa na Indústria Automóvel Mundial. Unpublished Ph.D Thesis, ISEG, Lisboa.

GuERRA, A. (1993) - The international involvement of the Portuguese automobile industry. in V. C. SIMÕES (ed.). Proceedings of the 19th Annual Conference of EIBA, vol. I, Agir, Lisboa: 83-113.

HM GOVERnMENT (1994) - Competitiveness - Helping Business to Win. White Paper, Cm 2563. HMSO, London.

IMF (1995) - The Industry Recovers: More Jobs? or Longer Hours?. IMF Auto Report 1995, Automotive Department, International Metalworkers' Federation, Geneva.

IRS (1993) - The Impact of Japanese Firms on Working and Employment Practices in British Manufacturing Industry. Industrial Relations Service, London.

JONES, P. N.; R. J. NORTH (1991) - Japanese motor industry transplants: The Western European dimension. Economic Geography, 67: 105-123.

LiMA, M. P.; L. PIRES; P. Alves (1995) - Transformações das relações laborais em três sectores: os casos das indústrias automóvel, siderúrgica e naval. Análise Social, 30 (134): 857-879.

Marsden, D.; T. Morris; P. Willman; S. WoOD (1985) - The Car Industry: Labour Relations and Industrial Adjustment. Tavistock Publications, London.

MAYES, D.; Y. OGIWARA (1992) - Transplanting Japanese success in the UK. NIESR Review, 4 (142): 99-105.

MIE (1991) - The Automobile Industry and the Foreign Investment. MIE, Lisboa.

MoNIZ, A. B. (1993) - Estratégias de empresas transnacionais (TNE) em economias periféricas: o sector automóvel e o projecto Ford/VW em Portugal. in A. B. MoNIZ et al (ed.). The Spatial Influence of Industrial Development: The Portuguese Case, Projecto The Future of Industry in Europe, FAST-MONITOR, DG XII, CEG, Lisboa.

Morgan, K.; P. COOKE; A. PRICE (1992) - The Challenge of Lean Production for German Industry. Regional Industrial Research Report 12, Department of City and Regional Planning, University of Wales College of Cardiff.

MUNDAY, M.; J. MORRIS; B. WILKINSON (1995) - Factories or warehouses? a Welsh perspective on Japanese transplant manufacturing. Regional Studies, 29 (1): 1-17.

OLIVER, N.; B. WILKINSON (1990) - Contemporary industrial change: the implications of the 'Japanization' of British industry. in S. CROWTHER; P. GARRAHAN; P. STEWART (eds.). Restructuring for Economic Flexibility. Avebury, Aldershot.

OLIVER, N.; R. DELBRIDGE; J. LOWE (1993) - World Class Manufacturing: Further Evidence in the Lean Production Debate. University of Cambridge, Cambridge. Mimeo. 
PA CAMBridge ECONOMiC CONSUltancy (1995) - Assessment of the Wider Effects of Foreign Investment on Manufacturing in the UK. PA Cambridge Economic Consultancy, Cambridge.

PIKE, A. (1994) - 'New' Activities for 'Old Industrial Spaces'?: Restructuring the Global Automobile Industry and the Old Industrial Regions of the UK. Unpublished Ph. D Thesis, Department of Geography, University of Liverpool, Liverpool.

POLLERT, A. (1992) (ed.) - Farewell to Flexibility?. Unwin Hyman, London.

RuigroK, W.; R. VAn Tulder; G. BAVEn (1991) - Cars and Complexes: Globalisation versus Global Localization Strategies in the World Car Industry. Prospective Dossier 2, Volume 13, MONITOR/FAST Programme, DGXII, CEC, Brussels.

SADLER, D. (1993) - National and international regulatory frameworks: the politics of European automobile industry production and trade. in R. HuDSON; E. SCHAMP (eds.). Towards a New Map of Automobile Production in Europe? New Production Concepts and Regional Restructuring, Springer, Berlin.

SALAIS, R.; M. STORPER (1990) - One Industry, Multiple Rationalities: Flexibility and Mass Production in the French Automobile Industry. Discussion Paper D901, Graduate School of Architecture and Urban Planning, University of California, Los Angeles.

SMMT (1989) - SMMT Guide to Motor Manufacturing in Britain. SMMT, London.

TOMANEY, J. (1991) - Japanese Inward Investment and Regional Development. Paper for CLES Conference 'Japanese Inward Investment in the UK', Matlock, 31st January.

VALE, M. (1994) - Restructuring the automobile industry and the Southern and Eastern European regions. Regional Conference of IGU, Prague, CEG, EPRU 41: 51-64.

Williams, K.; C. HASLAM; J. WiLliams (1992) - Against lean production. Economy and Society, 21 (3): 321-354.

Williams, K.; C. Haslam; S. Johal; J. Williams (1994) - Cars: Analysis, History, Cases. Berghahn Books, Oxford.

Womack, J.; D. Jones; D. Roos (1990) - The Machine That Changed the World. Maxwell Macmillan International, New York.

Wood, S. (1992) - Debating Japanese Management: Post-Fordism or the Japanization of Fordism. Industrial Relations Department, London School of Economics, London. Mimeo. 